\title{
A molecular study of Neophyllaphis varicolor (Hemiptera, Aphididae) in Costa Rica
}

\author{
Adonay Zúñiga-Centeno', Izayana Sandoval-Carvajal², Mauricio Montero-Astúa 1,2, \\ William Villalobos-Muller ${ }^{2}$, Nguyễn Bảo Quốc ${ }^{3}$, Nicolás Pérez Hidalgo ${ }^{4}$ \\ I Universidad de Costa Rica, Escuela de Agronomía, San José, 11501-2060, Costa Rica 2 Universidad de \\ Costa Rica, Centro de Investigación en Biología Celular y Molecular, San José, 11501-2060, Costa Rica \\ 3 Nong Lam University, Research Institute for Biotechnology and Environment, Ho Chi Minh City, 700000, \\ Vietnam 4 Instituto de Biología Integrativa de Sistemas (I'SysBio), Centro Mixto Universidad de Valencia- \\ CSIC, Valencia, 46980, España
}

Corresponding author: Nicolás Pérez Hidalgo (nipehi@uv.es)

Academic editor: Roger Blackman | Received 5 April 2019 | Accepted 29 May 2019 | Published 22 July 2019

http://zoobank.org/2421E9B0-E7B6-431F-8BC2-15131BAB7351

Citation: Zúniga-Centeno A, Sandoval-Carvajal I, Montero-Astúa M, Villalobos-Muller W, Quốc NB, Pérez Hidalgo N (2019) A molecular study of Neophyllaphis varicolor (Hemiptera, Aphididae) in Costa Rica. ZooKeys 865: $123-135$. https://doi.org/10.3897/zookeys.865.35213

\begin{abstract}
The genus Neophyllaphis (Takahashi) (Aphididae: Neophyllaphidinae) is composed of 18 species; however, in the Americas only nine species have been reported previously. A new species, Neophyllaphis varicolor Miller \& Halbert, was described in 2014 in USA. Colonies resembling those of this new species have been observed in Costa Rica on Podocarpus spp. In order to determine if $N$. varicolor is also present in Costa Rica, we sampled Neophyllaphis colonies from Podocarpus falcatus and P. chinensis. Additionally, we sampled individuals from Podocarpus sp. in Spain and Vietnam. DNA of each sample was extracted and used to amplify and sequence the cytochrome $c$ oxidase subunit I (COI) and elongation factor I (EF-1 $\alpha)$ partial regions. According to morphological characteristics, sequences comparisons done in GenBank and BOLD, and phylogenetic analyses, the colonies collected from Podocarpus spp. in Costa Rica and the colony from Vietnam corresponded to the species $N$. varicolor. To the best of our knowledge this is the first report of the presence of $N$. varicolor in Central America and Vietnam.
\end{abstract}

\section{Keywords}

Aphids, cytochrome $c$ oxidase subunit I, DNA barcoding, elongation factor I, integrative taxonomy, phylogenetic analysis, Podocarpus

Copyright Adonay Zúniga-Centeno et al. This is an open access article distributed under the terms of the Creative Commons Attribution License (CC BY 4.0), which permits unrestricted use, distribution, and reproduction in any medium, provided the original author and source are credited. 


\section{Introduction}

Neophyllaphis Takahashi (Aphididae: Neophyllaphidinae) is a genus occurring predominantly in the southern hemisphere and composed of 18 species characterized by a body covered with pulverulence and waxy secretions, antenna with a short terminal process, siphuncular pores on small cones, cauda with a constriction in the middle and with a caudal knob, and annular secondary rhinaria that are only present in alatae (Quednau 2010). The species of this genus live on species of Podocarpaceae, Araucariaceae, Myrtaceae, and less frequently on Cupressaceae (Hales and Lardner 1988; Miller and Halbert 2014). The genus is divided into two subgenera, a nominotypical subgenus Neophyllaphis, and the subgenus Chileaphis Essig, 1953 (Hille Ris Lambers 1967). Species of the subgenus Chileaphis have a very restricted distribution in South America while the subgenus Neophyllaphis is distributed in temperate and tropical regions of Africa, Asia, and Australia, and some species have been introduced in North America (Hille Ris Lambers 1967; Russell 1982; Qiao et al. 2001; Blackman and Eastop 2019). In Europe, only the species Neophyllaphis podocarpi Takahashi 1920 has been reported (Aguiar et al. 2013; Pérez Hidalgo et al. 2015).

In the Americas there are nine Neophyllaphis species (Mier Durante et al. 2008; Quednau 2010; Miller and Halbert 2014; Blackman and Eastop 2019), six species in the subgenus Chileaphis and three invasive species in the subgenus Neophyllaphis: N. araucariae Takahashi 1937, N. podocarpi (Mier Durante et al. 2008; Quednau 2010), and the newest described as N. varicolor Miller and Halbert 2014. The species $N$. podocarpi and $N$. varicolor have been reported in the western hemisphere only in the United States. Both species have been recorded in Florida and Louisiana, while only N. podocarpi has been found in California, Mississippi, and Texas (Russell 1982; Skvarla et al. 2017). The species $N$. araucariae is the only one living on the genus Araucaria Juss. and it is native of the Oriental region (perhaps native to Norfolk Island or Australia). There are reports of $N$. araucariae in the United States (Florida, California, Hawaii) (Timberlake 1917; Russell 1982), Mexico (Peña-Martínez 1985), Panama (Russell 1982), Venezuela (Cermeli 1990) and Costa Rica (Voegtlin et al. 2003). In Costa Rica, it is the only reported species of Neophyllaphis (Voegtlin et al. 2003; Villalobos Muller et al. 2010).

The newly recorded species $N$. varicolor, described by Miller and Halbert (2014), is characterized by a dorsoventrally flattened body and color variations of individuals in the same colony that may be yellow, orange, red or purple. The species was noticed beginning in 2010 in different counties in Florida. There are no records from outside USA. Multi-colored aphid colonies resembling those described by Miller and Halbert (2014), were found infesting the trees Podocarpus falcatus (Thunb.) Mirb. and P. chinensis Wall. ex J.Forbes Wall. in Costa Rica during 2014 (Figure 1). Morphological identification and molecular analyses were done to determine if the new species, $N$. varicolor, is also present in Costa Rica. 


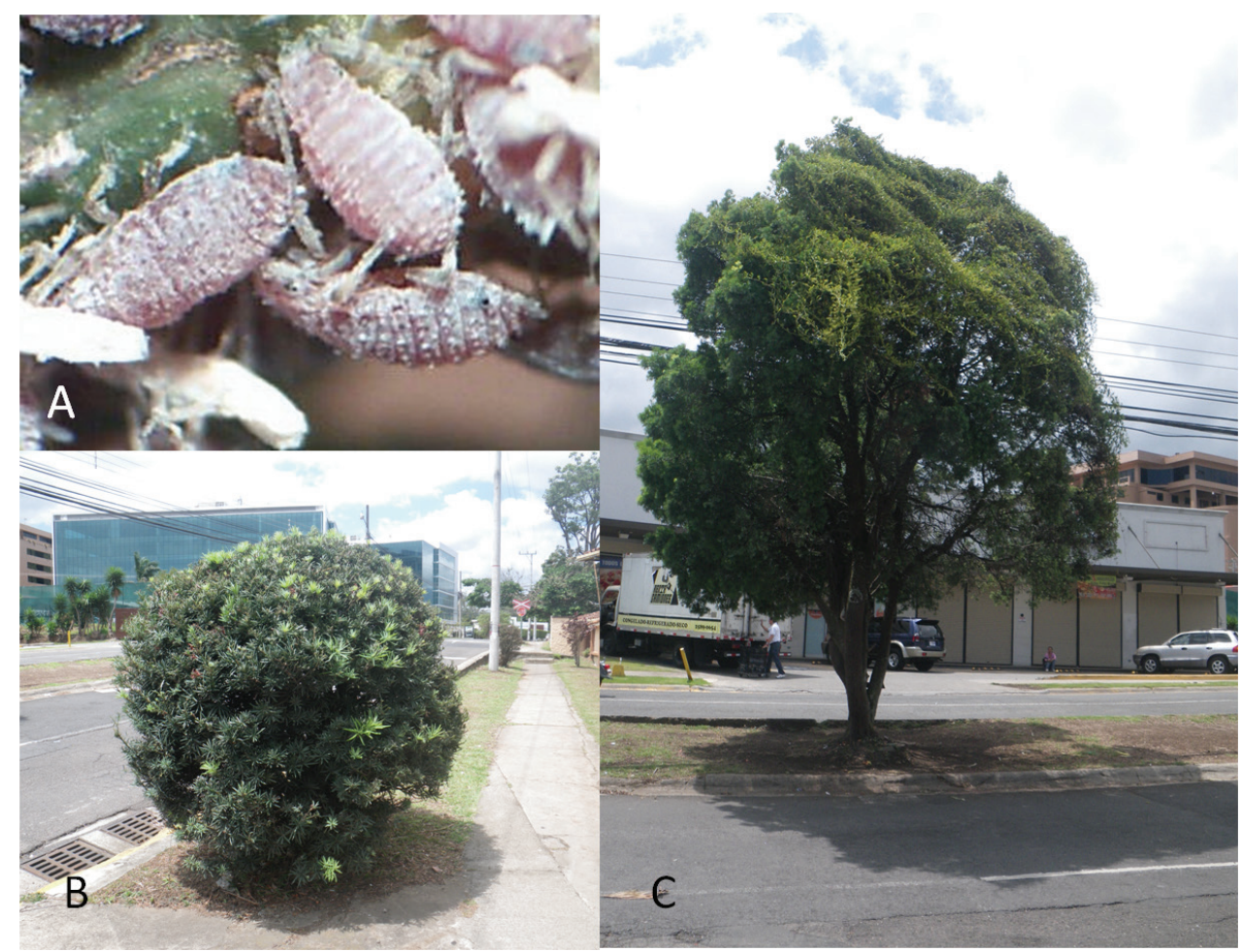

Figure I. A Neophyllaphis varicolor Miller \& Halbert, apterous individuals from Costa Rica B Podocarpus chinensis Wall. ex J.Forbes, and C Podocarpus falcatus (Thunb.) Mirb.

\section{Materials and methods}

\section{Sample collection}

Thirteen aphid colonies were sampled for this study. Nine samples from colonies on Podocarpus spp. L'Hér.ex Pers. were collected from different localities in San José province and samples from two colonies of $N$. araucariae were collected on Araucaria spp. in San José and Cartago provinces (Costa Rica). Additionally, two samples, one of $N$. podocarpi from Gerona (Spain) and one Neophyllaphis sp. multicolored colony from a Podocarpus sp. shrub in Vietnam were collected for comparison (Table 1). Samples were maintained at $-35^{\circ} \mathrm{C}$ in $95 \%$ ethanol for molecular analyses and at $6{ }^{\circ} \mathrm{C}$ in $70 \%$ ethanol for morphological analysis.

\section{Morphological identification}

Individuals preserved in $70 \%$ ethanol were cleared using $\mathrm{KOH}$ and acetic acid and mounted in slides with Canada balsam. The morphological identification of the 
Table I. Samples of Neophyllaphis spp. colonies (individual aphids per colony indicated by a, b, and c) and the corresponding accession numbers of COI and EF- $1 \alpha$ sequences deposited at GenBank.

\begin{tabular}{|c|c|c|c|c|c|c|}
\hline \multirow[t]{2}{*}{ Species } & \multirow{2}{*}{$\begin{array}{l}\text { Colony } \\
\text { code }\end{array}$} & \multirow[t]{2}{*}{ Collection place } & \multirow[t]{2}{*}{ Host plant } & \multicolumn{3}{|c|}{ Accession numbers } \\
\hline & & & & & $\mathrm{COI}$ & EF-1 $\alpha$ \\
\hline \multirow[t]{3}{*}{ N. varicolor } & \multirow[t]{3}{*}{ CR14-002 } & \multirow{3}{*}{$\begin{array}{l}\text { Montes de Oca, San José }\left(9.935764^{\circ} \mathrm{N} \text {, }\right. \\
\left.84.057778^{\circ} \mathrm{W}\right)\end{array}$} & Podocarpus falcatus (Thunb.) & $\mathrm{a}$ & MK174294 & ND \\
\hline & & & Mirb. & $\mathrm{b}$ & MK174295 & MK174326 \\
\hline & & & & c & MK174296 & MK174327 \\
\hline \multirow[t]{3}{*}{ N. varicolor } & \multirow[t]{3}{*}{ CR14-004 } & \multirow{3}{*}{$\begin{array}{l}\text { Montes de Oca, San José }\left(9.934636^{\circ} \mathrm{N} \text {, }\right. \\
\left.\qquad 84.058056^{\circ} \mathrm{W}\right)\end{array}$} & Podocarpus chinensis Wall. ex & a & MK174297 & ND \\
\hline & & & J.Forbes & $\mathrm{b}$ & MK174298 & ND \\
\hline & & & & c & MK174299 & MK174328 \\
\hline \multirow[t]{3}{*}{ N. varicolor } & \multirow[t]{3}{*}{ CR14-005 } & \multirow{3}{*}{$\begin{array}{l}\text { Montes de Oca, San José }\left(9.934567^{\circ} \mathrm{N} \text {, }\right. \\
\left.84.059167^{\circ} \mathrm{W}\right)\end{array}$} & Podocarpus falcatus (Thunb.) & $\mathrm{a}$ & MK174300 & ND \\
\hline & & & Mirb. & $\mathrm{b}$ & MK174301 & MK174329 \\
\hline & & & & c & MK174302 & ND \\
\hline \multirow[t]{3}{*}{ N. varicolor } & \multirow[t]{3}{*}{ CR14-012 } & Goicoechea, San José $\left(9.946283^{\circ} \mathrm{N}\right.$, & Podocarpus falcatus (Thunb.) & a & MK174303 & MK174330 \\
\hline & & $\left.84.053056^{\circ} \mathrm{W}\right)$ & Mirb. & $\mathrm{b}$ & MK174304 & ND \\
\hline & & & & c & MK174305 & ND \\
\hline \multirow[t]{3}{*}{ N. varicolor } & \multirow[t]{3}{*}{ CR14-013 } & Curridabat, San José $\left(9.923417^{\circ} \mathrm{N}\right.$, & Podocarpus falcatus (Thunb.) & $\mathrm{a}$ & MK174306 & MK174331 \\
\hline & & $\left.84.033056^{\circ} \mathrm{W}\right)$ & Mirb. & $\mathrm{b}$ & MK174307 & ND \\
\hline & & & & c & MK174308 & ND \\
\hline \multirow[t]{2}{*}{ N. varicolor } & \multirow[t]{2}{*}{ CR14-033 } & Montes de Oca, San José $\left(9.943450^{\circ} \mathrm{N}\right.$, & Podocarpus chinensis Wall. ex & $\mathrm{b}$ & MK174309 & ND \\
\hline & & $\left.84.018889^{\circ} \mathrm{W}\right)$ & J.Forbes & c & MK174310 & MK174332 \\
\hline \multirow[t]{3}{*}{ N. varicolor } & \multirow[t]{3}{*}{ CR14-034 } & Montes de Oca, San José $\left(9.939783^{\circ} \mathrm{N}\right.$, & Podocarpus falcatus (Thunb.) & a & MK174311 & ND \\
\hline & & $\left.84.009444^{\circ} \mathrm{W}\right)$ & Mirb. & $\mathrm{b}$ & MK174312 & MK174333 \\
\hline & & & & c & MK174313 & ND \\
\hline \multirow[t]{3}{*}{ N. varicolor } & \multirow[t]{3}{*}{ CR14-127 } & San José, San José (9.929947N, & Podocarpus falcatus (Thunb.) & a & MK174314 & ND \\
\hline & & $\left.84.070278^{\circ} \mathrm{W}\right)$ & Mirb. & $\mathrm{b}$ & MK174315 & ND \\
\hline & & & & c & MK174316 & MK174334 \\
\hline \multirow[t]{3}{*}{ N. varicolor } & \multirow[t]{3}{*}{ CR14-295 } & Vázquez de Coronado, San José $\left(9.969086^{\circ} \mathrm{N}\right.$, & Podocarpus falcatus (Thunb.) & a & MK174317 & MK174335 \\
\hline & & $\left.84.016944^{\circ} \mathrm{W}\right)$ & Mirb. & $\mathrm{b}$ & MK174318 & ND \\
\hline & & & & c & MK174319 & ND \\
\hline \multirow[t]{2}{*}{ N. araucariae } & CR14-364 & Paraíso, Cartago $\left(9.852750^{\circ} \mathrm{N}, 83.807500^{\circ} \mathrm{W}\right)$ & Araucaria araucana (Molina) & $\mathrm{b}$ & MK174320 & MK174336 \\
\hline & & & K. Koch & c & MK174321 & MK174337 \\
\hline$N \cdot$ podocarpi & CR14-398 & Gerona, Spain $\left(41.676944^{\circ} \mathrm{N}, 2.801944^{\circ} \mathrm{W}\right)$ & Podocarpus neriifolius D.Don & c & MK174325 & MK174341 \\
\hline N. varicolor & CR14-397 & Long Dinh, Vietnam $\left(10.384510^{\circ} \mathrm{N}\right.$ & Podocarpus sp. L’Hér.ex Pers. & a & MK463550 & MK463553 \\
\hline & & $\left.106.166800^{\circ} \mathrm{W}\right)$ & & $\mathrm{b}$ & MK463551 & MK463554 \\
\hline & & & & c & MK463552 & MK463555 \\
\hline N. araucariae & CR14-423 & Vázquez de Coronado, San José $\left(9.970153^{\circ} \mathrm{N}\right.$, & Araucaria heterophylla & a & MK174322 & MK174338 \\
\hline & & $\left.84.030833^{\circ} \mathrm{W}\right)$ & (Salisb.) Franco & $\mathrm{b}$ & MK174323 & MK174339 \\
\hline & & & & c & MK174324 & MK174340 \\
\hline
\end{tabular}

specimens was done using a Leica Z16 microscope. We measured structures with taxonomic value and used the keys from Miller and Halbert (2014) and Blackman and Eastop (2019) to identify species of Neophyllaphis. The photographs were taken with a Leica Z16 microscope, equipped with a CF500 camera and LAS 4.9 (Leica) image capture. Mounted specimens were deposited at the aphid collection of the Instituto de Biología Integrativa de Sistemas (Centro Mixto Universidad de Valencia-CSIC, Spain) and in the Centro de Investigación en Biología Celular y Molecular (CIBCM), Universidad de Costa Rica. 


\section{DNA extraction and molecular identification}

DNA was extracted from three individual aphid specimens per colony (preserved in 95\% ethanol) using the animal tissue protocol of NucleoSpin Tissue extraction kit (Macherey-Nagel, Germany) following the manufacturer instructions with a modification at the elution step; it was made by duplicate, using $50 \mu \mathrm{L}$ of elution buffer each time.

For the molecular identification and phylogenetic analysis of the Neophyllaphis spp. samples, we amplified the cytochrome $c$ oxidase subunit I (COI) and the elongation factor $1 \alpha(\mathrm{EF}-1 \alpha)$ genes. To amplify COI we used the primer pair C1-J-1490 (= LepF) and C1-N-2198 (= LepR) to obtain an amplicon of 658 bp (Hajibabaei et al. 2006, Miller and Halbert 2014), and the primers C1-J-1718 (Simon et al. 1994) and C1-J-2411 (Lagos et al. 2012) to obtain an amplicon of $868 \mathrm{bp}$. The EF-1 $\alpha$ gene was amplified using the primers EF-3 and EF-6 to generate a fragment of 785 bp (Miller and Halbert 2014). All PCR reactions were done in a final volume of $25 \mu \mathrm{L}$ with final concentration of $1 \mathrm{X}$ Dream Taq Master Mix (2X, Thermo Scientific, Lithuania), $200 \mathrm{nM}$ of each primer, 1\% trehalose dehydrated, and $5 \mu \mathrm{L}$ of DNA. Reactions were run with the following thermocycle profiles: $94^{\circ} \mathrm{C}$ x $1 \mathrm{~min} ; 5 \mathrm{x}\left(94^{\circ} \mathrm{C}\right.$ x 40 s, $45^{\circ} \mathrm{C}$ x 40 s, $72^{\circ} \mathrm{C}$ x $\left.1 \mathrm{~min}\right) ; 35 \mathrm{x}\left(94^{\circ} \mathrm{C}\right.$ x $40 \mathrm{~s}, 51^{\circ} \mathrm{C}$ x $40 \mathrm{~s}, 72^{\circ} \mathrm{C}$ x $1 \mathrm{~min}$ ); $72{ }^{\circ} \mathrm{C}$ x 5 min (Hajibabaei et al. 2005) for primer pair C1-J-1490 / C1-N-2198; and $96^{\circ} \mathrm{C}$ x 2 min; 40 x $\left(95^{\circ} \mathrm{C}\right.$ x 30 s, $53{ }^{\circ} \mathrm{C}$ x 30 s, 72 ${ }^{\circ} \mathrm{C}$ x $2 \mathrm{~min}$ ); $72{ }^{\circ} \mathrm{C}$ x $10 \mathrm{~min}$ for primers C1-J-1718 / C1-J-2411 (Lagos et al. 2012).

Amplicons of COI and EF-1 $\alpha$ were directly sequenced after purification in reverse and forward directions by the Sanger method (Macrogen, Korea). The final contigs were obtained using BIOEDIT 7.0 (Hall 1999) and were assigned preliminarily to a species by alignment using the BLAST tool of NCBI (Altschul et al. 1990) and the Identification Engine tool at BOLD (Ratnasingham and Hebert 2007). Sequences obtained are available in GenBank (Table 1).

\section{Phylogenetic analyses}

Phylogenetic analyses of Neophyllaphis spp. samples were done using partial sequences of the COI gene. Additionally, partial sequences of COI (nucleotide positions from 94 to 570 according to the reference sequence KF199852) and EF-1 $\alpha$ (nucleotide positions from 81 to 546 according to the reference sequence KF199851) were concatenated using BIOEDIT tool (Hall 1999) and a phylogenetic tree was generated. Phylogenetic analyses were done using a mixed model of Bayesian phylogenetic inference in MrBayes tool using a Markov Chain Monte Carlo (MCMC) search with ten million generations (Huelsenbeck and Ronquist 2001). The trees were visualized and edited using the tool FigTREE v1.4.2 (Rambaut and Drummond 2012).

Sequences obtained from GenBank (www.ncbi.nlm.nih.gov/Genbank) of the species $N$. varicolor (COI: KF199852; EF-1 $\alpha$ : KF199851, USA), N. podocarpi (COI: EU701821, Japan and JQ920926, China), Neophyllaphis brimblecombei Carver (COI: JF883870, Australia) and from BOLD Systems (http://www.barcodinglife.org) for 
Neophyllaphis totarae Cottier (COI: RFBAD211_08, New Zealand) were included for comparison in the phylogenetic analyses. Sequences of Greenidea anonae (Pergande) (COI: JQ926000; EF-1 $\alpha$ : KF856808, China) and Greenidea psidii van der Goot (COI: JQ925937 and EF-1 $\alpha$ : KF856814, China, and COI: EU701673, USA) were used as an outgroup because the genus Greenidea clustered relatively close to Neophyllaphis in a COI phylogeny (Foottit et al. 2008).

\section{Results}

\section{Morphological identification}

The metric and meristic characters (including color when alive) of the approximately 70 apterous specimens (Figure 2) and of the 12 winged (Figure 3) of Neophyllaphis studied in Costa Rica and their comparison with the detailed description of $N$. varicolor by Miller and Halbert (2014), confirmed that the Costa Rican samples belong to this species described from North America. However, the Ant. III/Ant. IV ratios of our apterous specimens varied from 2.32 to $2.88(\bullet=2.56)$. Thus, the antennal ratio character used to separate Neophyllaphis fransseni Hille Ris Lambers and N. varicolor (ratio greater
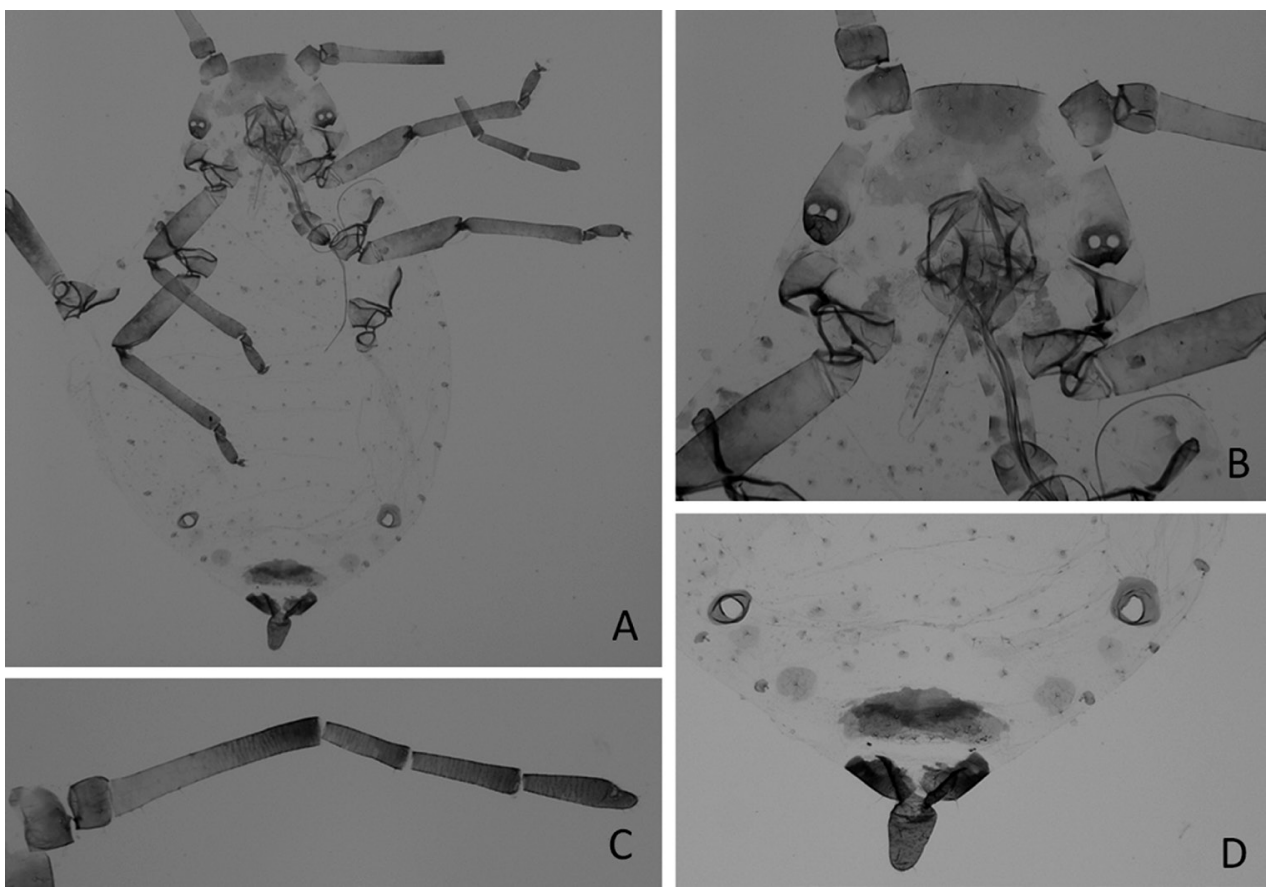

Figure 2. Neophyllaphis varicolor Miller \& Halbert, apterous A body B anterior part of the body $\mathbf{C}$ antennae, and $\mathbf{D}$ posterior part of body. 

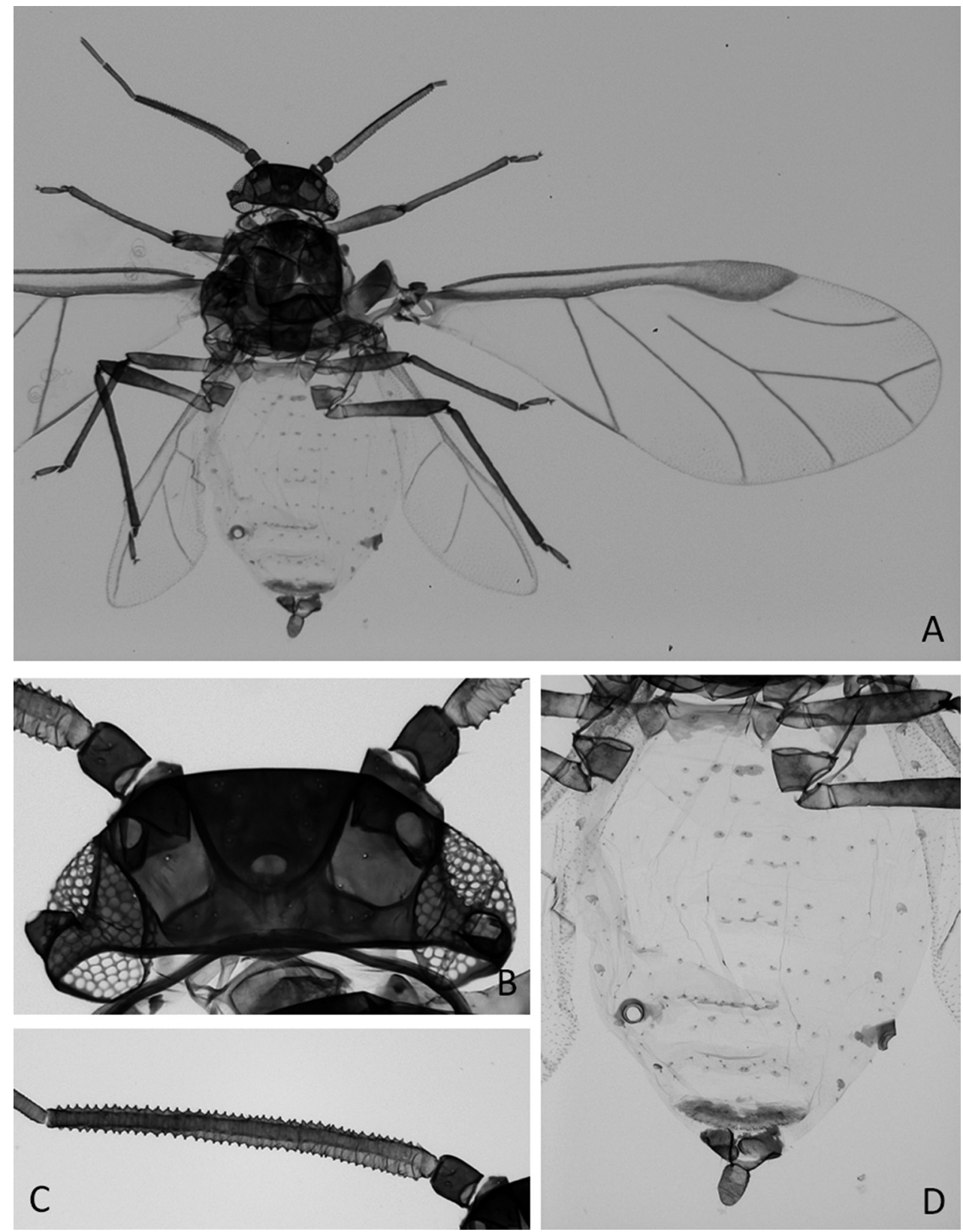

Figure 3. Neophyllaphis varicolor Miller \& Halbert, alate $\mathbf{A}$ alate aphid B head $\mathbf{C}$ antennal segment III and $\mathbf{D}$ abdomen.

than 2.6 in apterae) from Neophyllaphis gingerensis Carver, N. totarae, N. brimblecombei, Neophyllaphis lanata Hales \& Lardner and N. podocarpi (with a ratio shorter than 2.6), should be reevaluated (Miller and Halbert 2014; Blackman and Eastop 2019). 


\section{Molecular identification and phylogenetic analysis}

A total of 39 individual aphids was analyzed by molecular means; COI sequence data were obtained for 35 individuals and EF-1 $\alpha$ sequences for 19 individuals. We did not obtain final sequences for all three aphid individuals processed per colony because amplifications failed for some individuals or the sequencing reaction rendered low quality reads. All COI and EF- $1 \alpha$ sequences obtained from samples morphologically identified as $N$. varicolor corresponded to this species according to the identification made in BOLD systems with 99.5\% (KF199852.1) and 99.7\% (KF199851.1) of similarity, respectively. It was not possible to corroborate the identification of the species $N$. araucariae by sequence identity comparison because data for this species is not available at GenBank or BOLD.

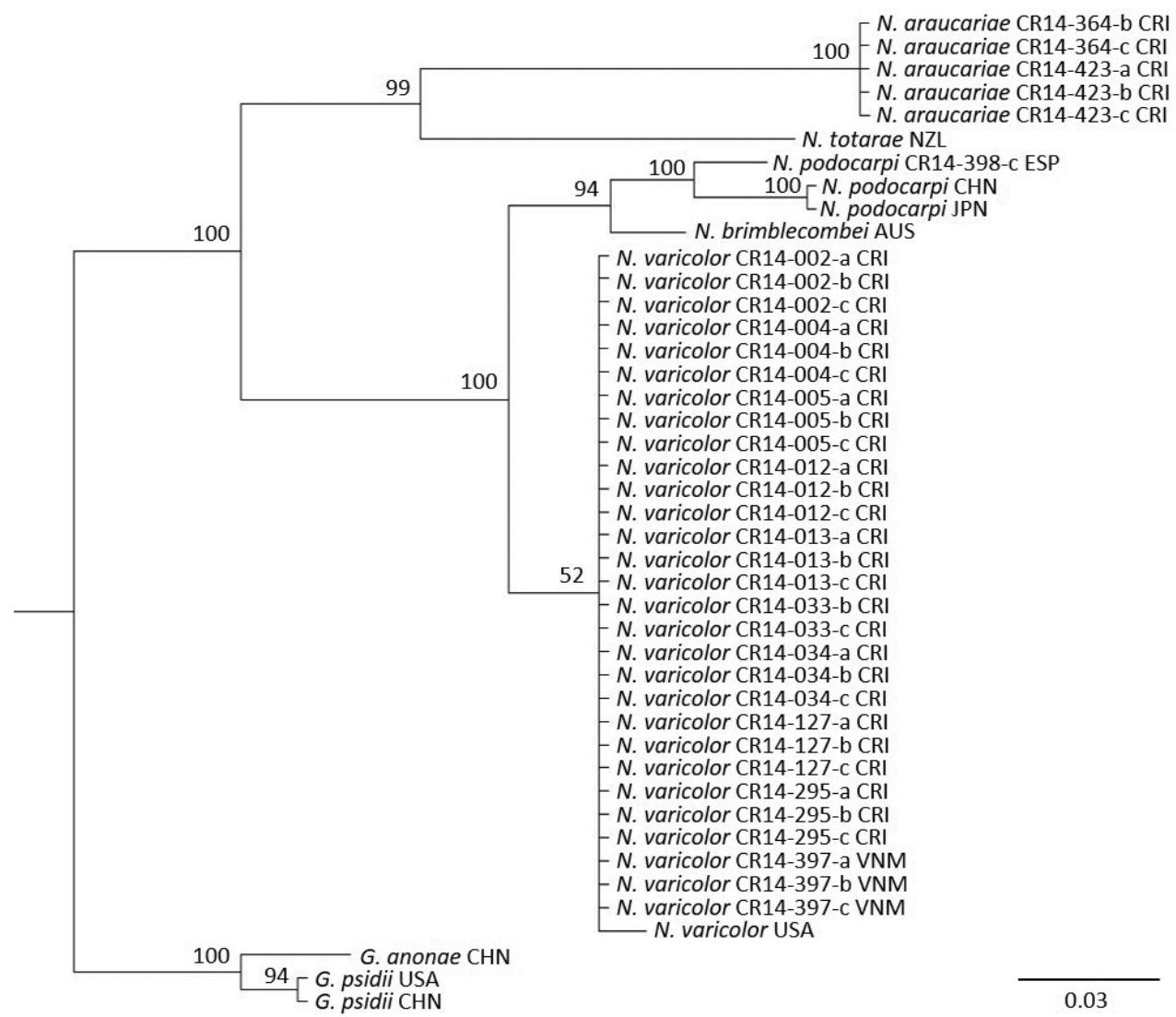

Figure 4. Phylogenetic analysis of Neophyllaphis araucariae Takahashi, Neophyllaphis brimblecombei Carver, Neophyllaphis podocarpi Takahashi, Neophyllaphis totarae Cottier, and Neophyllaphis varicolor Miller \& Halbert, using sequences of cytochrome c oxidase subunit I, made with Bayesian inference and using as outgroup Greenidea psidii van der Goot. and Greenidea anonae (Pergande). Sequence codes: species name - colony code - (a, b or c represent the specimen sampled) - country code. Key: AUS: Australia, CHN: China, CRI: Costa Rica, ESP: Spain, JPN: Japan, NZL: New Zealand, USA: United States, VNM: Vietnam. Scale bar represents 0.03 changes per site. 
All COI sequences of $N$. varicolor from Costa Rica were identical, while, EF-1 $\alpha$ sequences showed $0.6 \%$ difference. Sequences of COI and EF- $1 \alpha$ of $N$. araucariae did not show intraspecific variation. Interspecific genetic variation between $N$. varicolor and $N$. araucariae was of $11.4 \%$ in COI sequences and $13.4 \%$ in EF- $1 \alpha$ sequences.

All 26 partial sequences of COI from individuals morphologically identified as $N$. varicolor were grouped within the same clade, together with the Neophyllaphis sp. sample from Vietnam and the reference sequence of $N$. varicolor (GenBank Acc. No. KF199852) from Florida. This clade clustered independently from available sequences for $N$. araucariae, $N$. brimblecombei, $N$. podocarpi, and $N$. totarae. Similarly, all COI sequences of $N$. araucariae were grouped in the same clade, supporting identifications by morphological characters for both species. The $N$. araucariae cluster showed more relatedness to $N$. totarae than to the clade comprising $N$. podocarpi, $N$. brimblecombei, and $N$. varicolor.

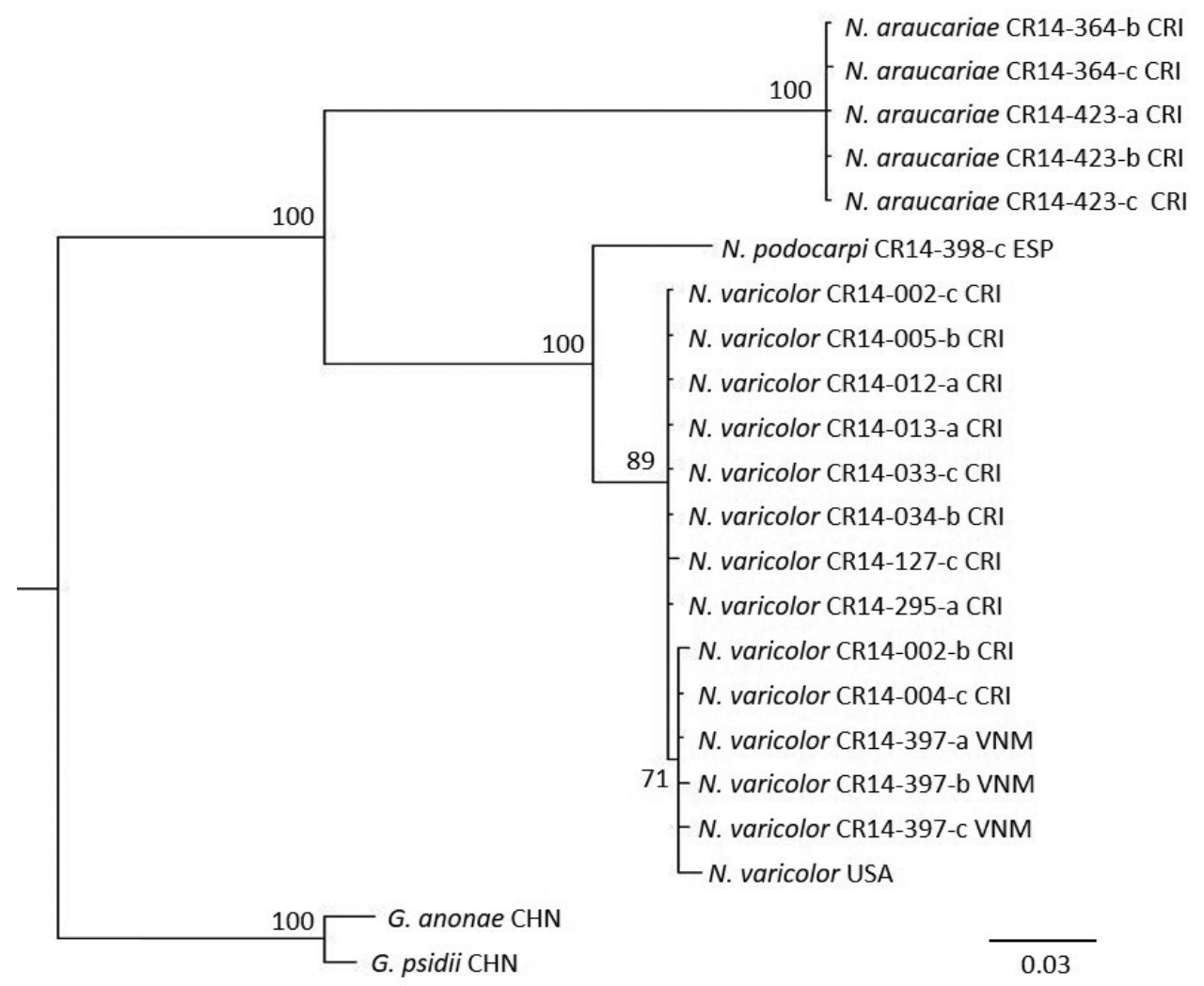

Figure 5. Phylogenetic analysis of Neophyllaphis araucariae Takahashi, Neophyllaphis podocarpi Takahashi and Neophyllaphis varicolor Miller \& Halbert, using concatenated sequences of cytochrome $c$ oxidase subunit I and elongation factor $1 \alpha$ made by Bayesian inference and using as outgroup Greenidea psidii van der Goot. and Greenidea anonae (Pergande). Sample names: species name - colony code - (a, b or c represent the specimen sampled) - country code. Key: CHN: China, CRI: Costa Rica, ESP: Spain, USA: United States, VNM: Vietnam. Scale bar represents 0.03 changes per site. 
The phylogenetic analysis made with a concatenated sequence composed of partial $\mathrm{COI}$ and EF- $1 \alpha$ sequences showed a clade grouping all the sequences of $N$. varicolor and another clade with the sequences of $N$. araucariae, in accordance with the COI phylogenetic tree (Figure 4) and with the morphological identification (Figure 5).

\section{Discussion}

According to our results, the recently described aphid species $N$. varicolor also is present in Costa Rica and Vietnam. In addition to $N$. varicolor sequence information for Costa Rica and Vietnam, we also generated and submitted partial COI and EF- $1 \alpha$ sequences for the species $N$. araucariae to GenBank for the first time. Indeed, we found few sequences available for the genus Neophyllaphis in public databases. Publicly available sequence information for all the describe species is important for comprehensive studies of the genus.

The morphological studies and molecular comparisons of COI and EF- $1 \alpha$ sequences, supported the description of the new, distinct species, N. varicolor on Podocarpus spp. (Miller and Halbert 2014). All COI and EF- $1 \alpha$ sequences of $N$. varicolor showed less than $0.5 \%$ of difference to the reference $N$. varicolor sequences deposited in GenBank. Previous studies have determined that the intraspecific variation in aphids is circa $0.6 \%$ in most of the species. There are some exceptions, like Neomyzus circunflexus (Buckton), with 3.14\%, the species with the highest intraspecific variation in COI out of 300 aphid species included in the study by Foottit et al. (2008).

The COI gene was characterized by a high interspecific variation (Floyd et al. 2009). The level of interspecific variation of COI (11.4\%) and EF- $1 \alpha(13.4 \%)$ observed between sequences of $N$. varicolor and $N$. araucariae from Costa Rica, was congruent with the high genetic divergence expected between different species. However, in some cases, the interspecific variation of COI between congeneric species could be less than 1\% (Chen et al. 2012).

According to our phylogenetic analyses made with COI region, the species $N$. podocarpi and $N$. brimblecombei are most related to $N$. varicolor, similar to findings by Miller and Halbert (2014); however, few sequences of Neophyllaphis species are available in GenBank or BOLD, so many species are not represented in the phylogenetic analysis. Previous studies have reported that $N$. podocarpi and $N$. brimblecombei have the same number of chromosomes and high morphological similarity, which suggest a recent separation between the species (Hales and Lardner 1988). Therefore, it is plausible to hypothesize that both species also were separated recently from $N$. varicolor in evolutionary time.

Our discoveries of $N$. varicolor in Costa Rica and Vietnam represent the first time that N. varicolor is reported outside of the USA. Currently, the genus Neophyllaphis is thus represented by two species in Costa Rica: $N$. varicolor and $N$. araucariae.

The presence in Vietnam of $N$. varicolor suggests that it is a species native to Southeast Asia. However, the genus Neophyllaphis presents taxonomic problems (Blackman and Eastop 2019) that must be solved with a good taxonomic, bionomic and molecular revisions. A full revision of the genus might shed better light on the geographic origins of the different species (Nibouche et al. 2018). 


\section{Acknowledgments}

This research, and the scientific visit of NPH to the CIBCM in 2014, were funded by University of Costa Rica (grants 801-B7-169 and 801-A1-801) and the investigation in Spain was conducted in the context of Project CGL2015-68188-P, funded by "Ministerio de Economía, Industria y Competitividad" (MIMECO) of Spain. The authors appreciate the comments and corrections made by Susan Halbert and Roger Blackman.

\section{References}

Aguiar AMF, Ilharco FA, Khadem M, Moreira M (2013) New records of aphids (Hemiptera: Aphidoidea) from Madeira and Azores Archipelagos. Entomologist's Monthly Magazine 149: 235-254.

Altschul SF, Gish W, Miller W, Myers EW, Lipman DJ (1990) Basic local alignment search tool. Journal of Molecular Biology 215: 403-410. https://doi.org/10.1016/S00222836(05)80360-2

Blackman RL, Eastop VF (2019) Aphids on the world's plants: an online identification and information guide. http://www.aphidsonworldsplants.info [Accessed 3 February 2019].

Cermeli M (1990) Lista actualizada de especies de áfidos (Homoptera, Aphidoidea) de Venezuela. Boletín Entomología Venezolana 5: 183-187.

Chen R, Jiang LY, Qiao GX (2012) The effectiveness of three regions in mitochondrial genome for aphid DNA barcoding: a case in Lachininae. PLoS ONE 8: 10-1371. https://doi. org/10.1371/journal.pone.0046190

Floyd RM, Wilson JJ, Hebert PD (2009) DNA barcodes and insect biodiversity. In: John Wiley, Sons (Eds) Insect Biodiversity: Science and Society. Blackwell publishing, Oxford, United Kingdom, 417-431. https://doi.org/10.1002/9781444308211.ch17

Foottit RG, Maw HE, Von Dohlen CD, Hebert PD (2008) Species identification of aphids (Insecta: Hemiptera: Aphididae) through DNA barcodes. Molecular Ecology Resources 8: 1189-1201. https://doi.org/10.1111/j.1755-0998.2008.02297.x

Hajibabaei M, Janzen DH, Burns JM, Hallwachs W, Hebert PDN (2006) DNA barcodes distinguish species of tropical Lepidoptera. Proceedings of the National Academy of Sciences of the USA 103: 968-971. https://doi.org/10.1073/pnas.0510466103

Hajibabaei M, deWaard JR, Ivanova NV, Ratnasingham S, Dooh RT, Kirk SL, Mackie PM, Hebert PDN (2005) Critical factors for assembling a high volume of DNA barcodes. Philosophical Transactions of the Royal Society B 360: 1959-1967. https://doi.org/10.1098/ rstb.2005.1727

Hales DF, Lardner R (1988) Genetic evidence for the occurrence of a new species of Neophyllaphis Takahashi (Homoptera: Aphididae) in Australia. Australian Journal of Entomology 27: 81-85. https://doi.org/10.1111/j.1440-6055.1988.tb01150.x

Hall TA (1999) BioEdit: a user-friendly biological sequence alignment editor and analysis program for Windows 95/98/NT. Nucleic Acids Symposium Series No 41: 95-98.

Hille Ris Lambers D (1967) On the genus Neophyllaphis Takahashi, 1920 (Homoptera, Aphididae) with descriptions of two new species. Zoologische Mededelingen 42: 55-66. 
Huelsenbeck JP, Ronquist F (2001) MRBAYES: Bayesian inference of phylogenetic trees. Bioinformatics 17: 754-755. https://doi.org/10.1093/bioinformatics/17.8.754

Lagos DM, Puttler B, Voegtlin DJ, Giordano R (2012) A new species of Aphis (Hemiptera: Aphididae) in Missouri on St. John's Wort, Hypericum kalmianum, and re-description of Aphis hyperici Monell. Zootaxa 3478: 81-92.

Mier Durante MP, Nieto Nafría JM, Delfino MÁ, Ortego J, Quednau FW (2008) Two South American new species of Neophyllaphis subgenus Chileaphis (Hemiptera: Aphididae). Florida Entomologist 91: 359-366. https://doi.org/10.1653/0015-4040(2008)91[359:TSAN $\mathrm{SO}$ 2.0.CO;2

Miller GL, Halbert SE (2014) A new species of Neophyllaphis (Hemiptera: Aphididae: Neophyllaphidinae) with keys to species on Podocarpus (Pinales: Podocarpaceae). Proceedings of the Entomological Society of Washington 116: 69-79. https://doi.org/10.4289/00138797.116.1.69

Nibouche S, Costet L, Holt JR, Jacobson A, Pekarcik A, Sadeyen J, Armstrong JS, Peterson GC, McLaren N, Medina RF (2018) Invasion of sorghum in the Americas by a new sugarcane aphid (Melanaphis sacchari) superclone. PLoS ONE 13: e0196124. https://doi. org/10.1371/journal.pone.0196124

Peńa-Martínez R (1985) Ecological notes on aphids of the high plateau of Mexico, with a checklist of species collected in 1980. In: Biosystematic and evolution of aphids. Proceedings of the International Symposium of Polska Akademia Nauk, Jablonna, Poland, 5-11 Apr 1981, 425-430.

Pérez Hidalgo N, Hernández-Castellano C, García-Figueres F (2015) First record of Neophyllaphis podocarpi Takahashi (Hemiptera: Aphididae) in the Iberian Peninsula. EPPO Bulletin 45: 103-105. https://doi.org/10.1111/epp.12177

Qiao GX, Zhang GX, Cao Y (2001) The genus Neophyllaphis Takahashi (Homoptera: Aphididae) from China with description of one new species. Oriental Insects 35: 91-96. https:// doi.org/10.1080/00305316.2001.10417290

Quednau FW (2010) Atlas of the Drepanosiphine aphids of the world. Part III: Mindarinae Tullgreen, 1909 to Saltusaphidinae Baker 1920 (Hemiptera: Sternorrhyncha, Aphididae). Memoirs of the American Entomological Institute 83: 1-361.

Rambaut A, Drummond A (2012) FigTree: tree figure drawing tool, v1. 4.2. Institute of Evolutionary Biology, University of Edinburgh. http://tree.bio.ed.ac.uk/software/figtree

Ratnasingham S, Hebert PDN (2007) BOLD: The barcode of life data system. Molecular Ecology Notes 7: 355-364. https://doi.org/10.1111/j.1471-8286.2007.01678.x

Russell LM (1982) The genus Neophyllaphis and its species (Hemiptera: Homoptera: Aphididae). Florida Entomologist 65: 538-573. https://doi.org/10.2307/3494690

Simon C, Frati F, Beckenbach A, Crespi B, Liu H, Flook P (1994) Evolution, weighting, and phylogenetic utility of mitochondrial gene sequences and a compilation of conserved polymerase chain reaction primers. Annals of the Entomological Society of America 87: 651701. https://doi.org/10.1093/aesa/87.6.651

Skvarla MJ, Halbert SE, Foottit RG, Jensen AS, Maw E, Miller GL (2017) An update to the adventive aphids (Hemiptera: Aphidoidea) of America north of Mexico, with notes on in- 
tercepted species. Proceedings of the Entomological Society of Washington 119: 90-111. https://doi.org/10.4289/0013-8797.119.1.90

Timberlake P (1917) Araucaria aphid. Proceedings of the Hawaiian Entomological Society 3: 267. Villalobos Muller W, Pérez Hidalgo N, Mier Durante MP, Nieto Nafría JM (2010) Aphididae (Hemiptera: Sternorrhyncha) from Costa Rica, with new records for Central America. Boletín de la Asociación Española de Entomología 34: 145-182.

Voegtlin D, Villalobos W, Sánchez MV, Saborío G, Rivera C (2003) A guide to the winged aphids (Homoptera) of Costa Rica. Revista de Biología Tropical 51: 1-214. 